\title{
Financial Literacy and the Success of Small Businesses: An Observation from a Small Business Development Center
}

\author{
Pearl Dahmen \\ University of South Florida, pjdahmen@usf.edu \\ Eileen Rodríguez \\ University of South Florida, erodrigu@usf.edu
}

Follow this and additional works at: https://digitalcommons.usf.edu/numeracy

Part of the Accounting Commons, and the Entrepreneurial and Small Business Operations Commons

\section{Recommended Citation}

Dahmen, Pearl, and Eileen Rodríguez. "Financial Literacy and the Success of Small Businesses: An Observation from a Small Business Development Center." Numeracy 7, Iss. 1 (2014): Article 3. DOI: http://dx.doi.org/10.5038/1936-4660.7.1.3 


\title{
Financial Literacy and the Success of Small Businesses: An Observation from a Small Business Development Center
}

\begin{abstract}
Small business is the backbone of the U.S. economy; when the financial literacy skills of entrepreneurs fall short of those needed to operate a successful business, it is more than the individual business at risk. In 2012, 14 small businesses requesting growth-acceleration consulting services from the Florida Small Business Development Center at the University of South Florida were assessed financially as part of the service provided by the Center. Financial ratios were used to analyze the business's financial condition. While performing the financial analysis of these firms, we also surveyed the business owners to determine their level of financial understanding and their use of financial statements in making management decisions. We found a strong association between the small businesses' financial strength and the business owners' habits of mind with regard to their financial statements: for $7 / 14$ of the businesses, the business owner did not regularly review financial statements, and 6/7 of those businesses were experiencing financial difficulties; conversely, $7 / 14$ of the businesses in the study were experiencing financial difficulties, and for $6 / 7$ of them, the business owner did not regularly review the financial statements.
\end{abstract}

\section{Keywords}

Small business, entrepreneurship, financial literacy, financial statements, financial ratios, quantitative literacy

\section{Creative Commons License}

\section{c) (7) (8)}

This work is licensed under a Creative Commons Attribution-Noncommercial 4.0 License

\section{Cover Page Footnote}

Pearl Dahmen Para is a Certified Public Accountant and was a Certified Business Analyst with the Florida Small Business Development Center at University of South Florida while preparing this paper. She is a PhD student in Education at the University of South Florida with current research interests in financial literacy, adult education, mobile and online learning, and MOOC (massive online learning courses).

Eileen Rodríguez is the Regional Director of the Florida Small Business Development Center at the University of South Florida. She holds an M.B.A and an M.S. in Geology from the University of South Florida, and a B.S. in Geology from the University of Puerto Rico - Mayagüez. She is a licensed Professional Geologist in the state of Florida and owned a geological consulting firm, Rodríguez Environmental, Inc., for four years.. She teaches the Introduction to Professional Geology course in the Professional Science Masters Program in the School of Geosciences at the University of South Florida and has taught small business management courses in the College of Business at USF. 


\title{
Introduction
}

The definition of Quantitative Literacy (QL) and Quantitative Reasoning (QR) in the VALUE Rubric of the Association of American Universities and Colleges $(\mathrm{AAC} \& \mathrm{U})^{1}$ says

Individuals with strong QL skills possess the ability to reason and solve quantitative problems from a wide array of authentic contexts and everyday life situations.

It is clear from the chapter headings in QL and QR textbooks (e.g., Sevilla and Somers 2007, Topic 9; Bennett and Briggs 2008, Chap. 4; Crauder et al. 2012, Chap. 4), papers in this journal (e.g., Gilliland et al. 2011; Lusardi 2012; Nye and Hillyard 2013) and the Financial Literacy theme collection in the previous issue (v. 6, issue 2, 2013) that authentic contexts and everyday life situations emphatically include financial contexts and financial life situations. Thus Financial Literacy (FL) figures prominently as an application of QL.

Although a consensus on the definition of FL had not been reached by 2010 , Remund (2010) synthesized a decade of describing FL conceptually as:

A measure of the degree to which one understands key financial concepts and possesses the ability and confidence to manage personal finances through appropriate, short-term decision-making and sound, long-range financial planning, while mindful of life events and changing economic conditions.

This operational definition, according to Remund (2010), encompasses the four most common areas: budgeting, savings, borrowing, and investing. Also in 2010, the U.S. Department of Treasury released the Federal Register Vol. 75. No. 168 defining five financial education core competencies: earning, spending, saving, borrowing, and protecting (e.g., insurance, identity theft) (U.S. Treasury 2010).

Thus far, discussions of FL in connection with QL have focused on personal finance - interest, inflation, credit card debt, and saving for retirement. We wish to call attention to another vital connection between FL and QL, one that comes out of the world of accounting: the ability and willingness to read financial statements. This skill, while important to investors, is critical to people who have a small business.

QL has been described as a "habit of mind," (Boersma and Klyve 2013). According to Costa (adapted from Kallick and Costa 2008):

\begin{abstract}
A "Habit of Mind" means having a disposition toward behaving intelligently when confronted with problems. When humans experience dichotomies, are confused by dilemmas, or come face to face with uncertainties - our most effective actions require drawing forth certain patterns of intellectual behavior. When we draw upon these intellectual resources, the results that are produced are more powerful, of higher quality and of greater significance than if we fail to employ those intellectual behaviors.
\end{abstract}

Nye and Hillyard (2013) state that financial QL positively correlates to financial behavior. It seems reasonable then to consider small-business FL is also a habit of mind and to expect that it will correlate with small-business success.

\footnotetext{
${ }^{1}$ http://www.aacu.org/value/rubrics/pdf/QuantitativeLiteracy.pdf (accessed Nov 30, 2013)
} 
In our experience with the Florida Small Business Development Center (SBDC) at the University of South Florida, the ability of a small business owner (entrepreneur) to garner information from a financial statement plays into the success of the small business. Specifically, can entrepreneurs detect symptoms in the financial statements that predict failure of their small businesses? More importantly: Do they even try? Or do they leave it all to the accountants? Therefore, for the purposes of this paper, we define Small-Business FL as the ability to understand and use business financial statements to generate key financial ratios to evaluate and manage a business. Here we report the findings on these questions from a study of 14 small firms who sought the assistance of the SBDC to achieve their desire to grow their business.

\section{Background}

\section{The SBA and SBDCs}

The U.S. Small Business Administration (SBA) was created in 1953 by an act of Congress in response to a growing awareness of the importance of small businesses to the national economy. Today, the SBA continues to provide resources to the over 23 million small businesses in the U.S. (SBA 2013a).

The SBA defines a small business based on the criteria and size standards in Title 13, Code of Federal Regulations, part 121. Whether a business qualifies as a "small" business will be determined by the size standards that have been established for their particular industry. The definition is based on either the number of employees in the company or the average annual receipts over the past three years (SBA 2013b).

In March 1977, Congress introduced The Small Business Development Center Act of 1977. The University of West Florida, which hosts the Florida SBDC Network (FSBDC), was one of the original eight universities chosen for the pilot program.

Today, all SBDCs provide services to small business owners, including unlimited no-cost, confidential, one-on-one consultation and low to no-cost training in the form of seminars and workshops. Across the U.S., including Puerto Rico, U.S. Virgin Islands, Guam, and American Samoa, 212,475 clients received consulting services and over 336,000 workshop attendees participated in SBDC training programs in 2012.

The Florida SBDC network is the second largest state network in the U.S. in terms of funding. The FSBDC consists of 12 regional centers that cover the State of Florida, from the Panhandle to the Keys. ${ }^{2}$ The FSBDC regional centers are exclusively hosted by institutions of higher education in the State of Florida. The FSBDC at the University of South Florida is the largest regional center in the state in terms of funding, and it provided consulting to 3,731 clients and training to 6,081 attendees in 2012 within a 10-county footprint. A staff of 44 professionals, Certified Business Analysts, provides consultation and instruction. One of the specialized services in the Center is the growth acceleration program (GAP), which was developed to assist existing businesses to expand and grow by

\footnotetext{
2 http://floridasbdc.org/locations.php (accessed Nov. 30, 2013)
} 
providing an in-depth business-health assessment review. SBDC consultants provide a minimum of 50 hours, and in some cases up to 120 hours of consultation per business. Targeted at assisting firms to investigate potential market-growth opportunities, consultants review the company's financial situation, assess the current cost structures, and develop a sustainable growth strategy. GAP consulting services are provided at no cost to the small business owner. To qualify, the company must have been in business for a minimum of three years, have five or more employees, have gross revenues between $\$ 500,000$ and $\$ 10$ million, ${ }^{3}$ and be considered in an industry with growth potential or selling a production service in demand. The 14 companies that participated in the study presented in this paper were GAP clients.

\section{Small Business}

Small business owners-typically referred to as entrepreneurs-vary in demographics. Women compose $30 \%$ of all entrepreneurs, while $13 \%$ of small businesses are minority owned (3.9\% African-American, 2.7\% Hispanic, and $1.9 \%$ Asian/Pacific). The median age of entrepreneurs is slightly more than 37 , the median age of the U.S. population, with $76 \%$ at least 45 years of age and $17 \%$ at 65 years or older. The educational levels of entrepreneurs also vary: $52 \%$ of entrepreneurs have a four-year college education; $29 \%$ have trade school training; $17 \%$ have a high-school diploma; and $2 \%$ did not finish high-school (SBA 2013c).

Since the 2007-2009 downturn in the United States economy, President Obama has turned to small business to support the economic recovery, calling small business "the backbone of the American Economy" (The White House Blog 2010). Small businesses contribute $46 \%$ of the gross domestic product (GDP), provide $49.2 \%$ of private sector employment, and make up $99.7 \%$ of U.S. employer firms. Unquestionably, small business owners are crucial to the nation's financial recovery and success. As a result, there have been increased efforts on the part of government agencies such as the SBA and SBDCs to grow the numbers of successful small businesses. The fact remains though that there is a high failure rate of small businesses. Various sources, including the U.S Census Bureau ${ }^{4}$, Shane (2012), and the Bureau of Labor Statistics ${ }^{5}$, over the past four decades have cited the failure rate of small businesses to be as high as $50 \%$ during the first five years of operations.

Ropega (2011) cites two main causes for small business failures in the United States based on the research of Bradley and Moore (2000). The first is inadequate management skills or poor knowledge of business. Ropega also reported results from a 2008 survey of Polish entrepreneurs indicating that the owner's lack of management knowledge contributed to $11.4 \%$ of the small business failures. The second cause of failure, according to Ropega, is insufficient capital, including excessive debt and poor capital management (33.5\% and $33 \%$, respectively, of respondents in the Polish study). These figures are reminiscent of those reported

\footnotetext{
${ }^{3}$ http://sbdctampabay.com/services/growth-acceleration-services/ (accessed Nov. 30, 2013)

4 http://www.census.gov/ces/dataproducts/bds/data firm.html (accessed Dec. 14, 2013)

5 http://bls.gov/bdm/entrepreneurship/bdm chart3.htm (accessed Dec. 14, 2013)
} 
by Lusardi (2012) with respect to deficiencies in the understanding of personal credit: fewer than $36 \%$ of research respondents correctly answered questions related to credit cards and interest rates, and over $20 \%$ indicated they did not know the answer.

\section{Financial Statements}

An understanding of the primary financial statements used in business-the balance sheet and income statement-is fundamental to FL for small business owners. The balance sheet represents the business's financial condition at a specific moment in time. It includes assets, liabilities, and equity. Assets are economic resources, anything tangible or intangible that is capable of being owned or controlled to produce value or that is held to have positive economic value. Liabilities are obligations of an entity arising from past transactions or events, the settlement of which may result in the transfer or use of assets or provision of services. Liabilities may also yield of economic benefits in the future. Equity is the residual claim or interest of assets, after all liabilities are paid. It represents the net worth of the business which is expressed as the owners' investment plus retained earnings. Total assets equal liabilities plus equity.

The income statement measures a company's financial performance over a specific accounting period, usually one month or one year. The statement is composed of revenues minus costs (cost of goods sold and operating expenses), with the result being net income (the bottom line). Revenues are what a company receives from its normal business activities, usually from the sale of goods and services to customers. Cost of goods sold is the direct costs attributable to the production of the goods sold or the delivery of services by a company. Expenses are the costs incurred in carrying out an organization's day-to-day activities, but not directly associated with production. Operating expenses include such things as payroll, transportation and travel, amortization and depreciation, rent, repairs, and taxes. Net income is a company's total earnings (or profit).

\section{Financial Ratios}

Berman et al. (2008) state that financial ratios are the window into a company's financial statements and offer understanding to what the financials are saying regardless of the company's size or years in business. When evaluating company financial statements, seven basic ratios can provide most of the information a business owner needs to evaluate and manage his or her business. Ednister (1972), Ohlson (1980), and Thomas and Evanson (1987) correlated the use of financial ratios and small business success using these ratios: gross profit percentage (gross margin), current ratio, debt ratio, days in accounts receivable, days in accounts payable, net profit ratio and return on investment. These basic business ratios are described in Table 1. Depending on the type of business and the situation, only a few of these ratios may be required to be managed.

Comparing these ratios for a particular firm to industry averages gathered by professional organizations such as the Risk Management Association (RMA) ${ }^{6}$ or industry associations can help a business owner benchmark his or her success.

\footnotetext{
${ }^{6}$ http://www.rmahq.org/ (accessed Nov. 30, 2013)
} 
The businesses considered here were evaluated as successful when ratios were at or better than industry standards; in contrast, ratios below industry standards indicated a need for improvement. In our experience, the evaluations based on these ratios corroborate the business owners' perception of their business's condition.

Table 1

Seven Basic Financial Ratios

\begin{tabular}{|c|c|c|}
\hline Ratio & Formula & Description \\
\hline Gross profit ratio & $\frac{\text { Sales }- \text { Cost of goods sold }}{\text { Sales }}$ & $\begin{array}{l}\text { Fundamental metric of a business's } \\
\text { financial performance. }\end{array}$ \\
\hline Current ratio & $\frac{\text { Current liabilities }}{\text { Current assets }}$ & $\begin{array}{l}\text { Indicates how well debt due within the } \\
\text { next } 12 \text { months can be paid. }\end{array}$ \\
\hline Debt ratio & $\frac{\text { Total liablities }}{\text { Total assets }}$ & $\begin{array}{l}\text { Indicates how well all debt can be } \\
\text { paid. }\end{array}$ \\
\hline Days in accounts receivable & $365 / \frac{\text { Sales }}{\text { Average accounts receivable }}$ & $\begin{array}{l}\text { Tells how many days there are } \\
\text { between the day an invoice is issued } \\
\text { and the day the payment is received. }\end{array}$ \\
\hline Days in accounts payable & $365 / \frac{\text { Cost of sales }}{\text { Average accounts payable }}$ & $\begin{array}{l}\text { Tells how many days the business is } \\
\text { taking to pay its bills. }\end{array}$ \\
\hline Net profit ratio & $\frac{\text { Net income }}{\text { Sales }}$ & $\begin{array}{l}\text { Tells the company's bottom line } \\
\text { profitability. }\end{array}$ \\
\hline Return on investment (ROI) & $\frac{\text { Net income }}{\text { Owner's investment }}$ & $\begin{array}{l}\text { Tells the company's bottom line } \\
\text { profitability. }\end{array}$ \\
\hline
\end{tabular}

Source: Farris et. al, 2010.

\section{Case Study}

\section{Methods}

The case study presented here is based on the business-health assessment review conducted during the period January 2012 and January 2013 by the GAP consultant at the SBDC at USF on 14 small businesses that requested GAP consulting services. The businesses owners self-selected by completing an application for GAP based on his or her own perceptions of needs and desires for consulting services to grow his or her business. Once applications were received by the SBDC, companies were evaluated against SBDC acceptance criteria. The decision to accept or reject a company into the program was made by an SBDC employee other than the authors. A trend emerged as a result of a review of the completed GAP reports for the 14 businesses.

The firms are from ten different industries, including medical supplies and devices, auto, technology, janitorial, legal, pet, construction, industrial supply, tanning, and health. Of the ten, four are manufacturers, three are distributors, six are service-based businesses, and one is a contractor. They represent small businesses that have a track record of being successful and have overcome the obstacles causing failure. Revenues for the businesses in this case study range from $\$ 500,000$ to $\$ 12.8$ million. The number of employees ranges from three to 
29. The length of time for business operations ranges from three to 43 years with longer-term businesses having second or third owners through purchase.

The owner(s) of each company participated in an extensive two- to three-hour interview. Interviews were conducted at the business location. The same questionnaire template is used for all GAP clients. This template is eight pages long and consists of 123 questions covering: business management; general business practices; marketing, sales and revenues; business products and/or services; competition; inventory; accounting practices; and employee policies and procedures. In addition, each owner was asked to provide three years of company tax returns and current year-to-date plus prior three years financial statements. The financial statements were reviewed for profitability and provided the primary data to calculate financial ratios.

Responses to interviews expanded the analysis of the financial statements and financial ratios to create an in-depth business assessment report. Excerpts of these interview data were then used to evaluate the business owners' relevant FL. The authors participated in carrying out the consulting services provided to the clients and did the data gathering and interpretation for the FL case study.

The 14 businesses were assessed for small-business financial literacy by interpreting the owner's comments during the interview as they related to financial statements and financial conditions. Table 2 includes questions asked of all 14 businesses, as well as questions derived from information provided by all respondents. First, each business owner was asked about the company's financial positioning for growth and whether it was currently having financial difficulty (questions 1 and 2 in Table 2). Then, each business owner was assessed for small-business FL. Four questions (questions $3-6$ in Table 2) were used to this end. In particular, questions 4 and 5 looked at financial habits and, therefore, are also QL questions (i.e., QL as a proactive habit of mind).

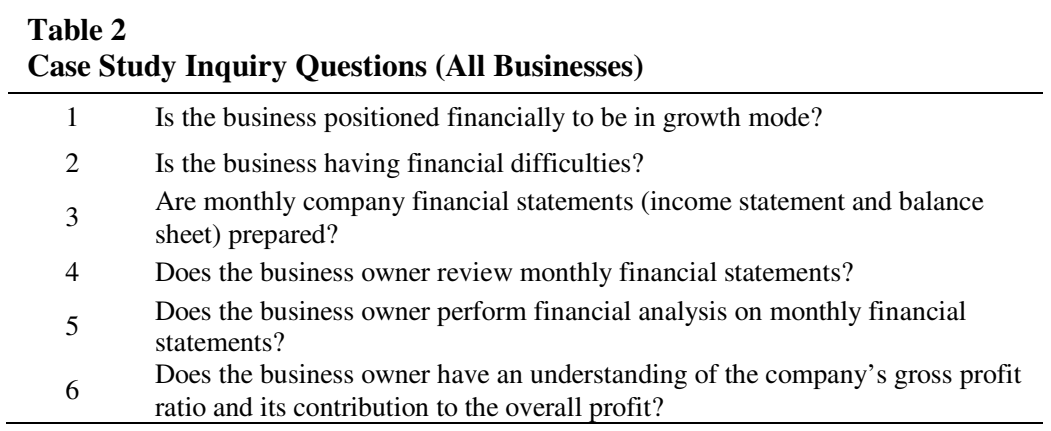

Businesses that were identified to have financial difficulties were given a second round of four questions, which are listed in Table 3. The last three of these were repeats of questions 4,5 , and 6 from the first round. The one new question (1) asks specifically about the fundamental gross profit ratio and is, accordingly, a FL question. The repetition of the two QL questions (4 and 5 from Table 2) aim to explore a possible connection between companies having financial difficulties and business owners ignoring financial statements. 
Table 3

Case Study Inquiry Questions (Firms with Financial Difficulties)

1 Is a poor gross profit ratio an indicator of the business's financial difficulties?

2 Does the business owner review monthly financial statements?

3 Does the business owner perform or review financial analysis on monthly financial statements?

4 Does the business owner have an understanding of the company's gross profit ratio and its contribution to the overall profit?

These final four questions (Table 3) address a possible association of a small business owner's FL/QL with the performance of his or her business. Concerning the merging of FL and QL here, we suspect that a business owner that does not review monthly financial statements or perform a monthly analysis of the business's financial statements may have a FL/QL problem, either substantively or attitudinally. Moreover, we suspect that the FL/QL problem is more likely present if the business owner perceives that the business is having financial difficulties and ignores the financial statements.

Age and education demographic data are not typically gathered in the SBDC consulting services, and therefore are not addressed here. Gender has been considered, while ethnicity is not disparate enough to provide meaningful data. Only one of the 14 businesses falls into a non-Caucasian category.

\section{Observations and Discussion}

Results of the inquiries are in Table 4, and more details are in the Appendix. Half (7/14) of the businesses requesting growth consulting were experiencing financial difficulties. The reasons for the financial difficulties fell into three categories: loss of revenues, insufficient cash flow, and excessive debt. In most cases, the loss of revenues was directly or indirectly related to the decline in the U.S. economy, which, of course, is out of the control of the business owner. On the other hand, insufficient cash flow and excessive debt are both areas that small business owners can manage, given sufficient FL.

Table 4

Results of Inquiries

\begin{tabular}{|c|c|c|}
\hline Question & Yes & No \\
\hline \multicolumn{3}{|l|}{ All Companies } \\
\hline \multicolumn{3}{|l|}{ State of the Business: } \\
\hline - Is the business positioned financially to be in growth mode? & $3 / 14$ & $11 / 14$ \\
\hline - Is the business having financial difficulties? & $7 / 14$ & $7 / 14$ \\
\hline \multicolumn{3}{|l|}{ Quantitative and Financial Literacy: } \\
\hline - Are monthly company financial statements (income statement and balance sheet) prepared? & $13 / 14$ & $1 / 14$ \\
\hline - Does the business owner review monthly financial statements? & $7 / 14$ & $7 / 14$ \\
\hline - Does the business owner perform financial analysis on monthly financial statements? & $3 / 14$ & $11 / 14$ \\
\hline $\begin{array}{l}\text { - Does the business owner have an understanding of the company's gross profit ratio and its } \\
\text { contribution to the overall profit? }\end{array}$ & $4 / 14$ & $10 / 14$ \\
\hline \multicolumn{3}{|l|}{ Companies with Financial Difficulties } \\
\hline - Is a poor gross profit ratio an indicator of the business's financial difficulties? & $4 / 7$ & $3 / 7$ \\
\hline - Does the business owner review monthly financial statements? & $1 / 7$ & $6 / 7$ \\
\hline Does the business owner perform financial analysis on monthly financial statements? & $0 / 7$ & $7 / 7$ \\
\hline
\end{tabular}


Of the seven firms experiencing financial difficulties, three were male owned and four were female owned. Financial analysis by the SBDC consultant indicated poor gross profit ratio (gross profit ratio below the industry average) clearly visible for two male-owned companies and two female-owned companies, four in total out of the seven companies experiencing financial difficulties. Only one of the owners of the companies with difficulties was reviewing monthly financial statements, and none of them performed any type of financial analysis (Table 4). When the subject of gross profit ratio was discussed, only one of the business owners had an understanding of the calculation of the company's percentage and its overall impact to the company's profit picture (Table 4).

Gross profit ratio was selected for the FL questions in this study (Table 2) because it is a key indicator of business performance; it is used to make fundamental business decisions, forecasts, and budgets. When used in pricing, the ratio is often confused with mark-up, the percentage based on cost rather than sales. Confusing mark-up with gross profit percentage can result in significant losses in gross profit and, in turn, business profits. Four of the 14 business owners in this study did not have a clear understanding of mark-up and gross profit. These are the same four businesses previously identified as showing poor gross profit ratios during financial analysis. Focusing on mark-up, contracts were priced to provide what the owner believed was ample revenue, when, in fact, the gross profit fell short. Additionally, not analyzing the financial statements to evaluate the company gross profit ratio kept this shortfall hidden until the SBDC consultant performed a complete financial review of the company.

Four out of the seven companies experiencing financial difficulties suffered from too much debt (Appendix). When a business owner does not follow and manage the liquidity and leverage ratios (the current ratio and the debt ratio), debt can grow and become unmanageable, impacting the business's ability to operate. Of the companies that exhibited too much debt, none of them reviewed or analyzed monthly financial statements.

Additionally, some of the studied businesses were experiencing difficulties with positive cash flow (Appendix). None of the businesses in this study were actively managing either the days in account receivable ratio or the days in accounts payable ratio (efficiency ratios).

As for the profitability and returns ratios (net profit ratio and return on investment), only three of the 14 companies in the study evaluated the ROI. None of the businesses with financial difficulties evaluated ROI.

Interviews with all business owners during the SBDC consulting engagements indicated the reason business owners are not performing financial reviews and analysis relate primarily to lack of understanding of what to look at and how to look at it-in other words, inadequate FL and QL in relation to business management (Appendix).

\section{Concluding Remarks}

This case study from the activities of an SBDC finds a clear connection between lack of or inadequate FL and financial difficulties experienced by entrepreneurs. The general pattern of inadequacies documented in this journal by Lusardi (2012) 
and Gilliland et al. (2011) with respect to debt and money management among consumers is apparently paralleled by comparable deficiencies for entrepreneurs. In our case study, $50 \%$ of business owners (7/14 businesses) did not regularly review financial statements, and 86\% (6/7) of those businesses were experiencing financial difficulties; conversely, 50\% (7/14) of the businesses in the study were experiencing financial difficulties, and for $86 \%(6 / 7)$ of them, the business owner did not regularly review the financial statements. More directly to the point of this paper: of the six businesses that were both experiencing financial difficulties and had owners who did not regularly review financial statements, $100 \%$ admitted that the owner's inadequate financial literacy was at the core of avoiding the review of the financial statements. This association between inadequate financial literacy and avoidance of the financial statements was a recurring theme through the interviews of this case study; it attests to the connection between financial literacy and overall business success.

The success of small businesses and the United States economy rests in the hands of small business owners. Although the nature of a case study as an indepth study of one or more instances of a phenomenon in real life context prohibits it from being generalized to an entire population (Gall et al. 2007), our study clearly suggests that small business owners would be well advised to master financial literacy, including the financial ratios that allow an understanding of their financial statements. Berman et al. (2008) emphatically state that financial literacy needs to become part of every businesses culture (Vacher 2014). Certainly, the general subject of a connection between inadequate small-business financial literacy and financially troubled small businesses is fertile ground for further study-sharing the landscape with connections between inadequate personal financial literacy and, for example, too much credit card debt or insufficient retirement planning.

\section{Acknowledgments}

We would like to thank Len Vacher and the four anonymous reviewers for their helpful suggestions for improving our paper. We also want to thank the Florida SBDC Network for allowing us to use their data for this research.

\section{References}

Bennett, Jeffrey O., and William L. Briggs. 2008. Using and understanding mathematics: A quantitative reasoning approach. Boston: Pearson Addison Wesley.

Berman, Karen, Joe Knight, with John Case. 2008. Financial intelligence for entrepreneurs: What you really need to know about the numbers. Boston: Harvard Business Press.

Boersma, Stuart and Dominic Klyve. 2013. Measuring habits of mind: Toward a prompt-less instrument for assessing quantitative literacy. Numeracy 6(1): Article 6. http://dx.doi.org/10.5038/1936-4660.6.1.6 (accessed Dec. 24, 2013). 
Bradley III, D. B. and H.L. Moore. 2000. Small business bankruptcy caused by lack of understanding and consumer needs, 1998 ICSB Sinapore Conference, http://www.sbaer.uca.edu/research/icsb/1998/88.pdf

Costa, Arthur L. Habits of Mind. http://www.habitsofmindinternational.com/store/clientimages/Habits_of_Min d_w_icons.pdf (accessed Dec. 24, 2013).

Crauder, B.C., B. Evan, J. A. Johnson, and A. V. Noell. 2012. Quantitative literacy: Thinking between the lines. New York: W. H. Freeman and Company.

Ednister, R. O. 1972. An Imperial test of financial ratio analysis for small business failure prediction. Journal of Financial \& Quantitative Analysis 7(2): 1477-1493. (Business Source Premier, EBSCOhost, accessed Oct. 30, 2013). http://dx.doi.org/10.2307/2329929

Farris, P. W., N. T. Bendle, P. E. Pfeifer, and D. J. Reibstein. 2010. Marketing metrics: The definitive guide to measuring marketing performance. Upper Saddle River NJ: Pearson Education.

Gall, M. D., J. P. Gall, and W. R. Borg. 2007. Educational Research An Introduction. New York: Pearson.

Gilliland, D., V. Melfi, A. Sikorskii, E. Corcoran, E. Melfi. 2011. Quantitative literacy at Michigan State University, 2: Connection to financial literacy, Numeracy 4 (2): Article 6 . http://dx.doi.org/10.5038/1936-4660.4.2.6 (accessed April 1, 2013).

Kallick, Bena, and Arthur L. Costa. 2008. Learning and Leading with Habits of Mind: 16 Essential Characteristics for Success. Alexandria, Va: Association for Supervision and Curriculum Development. (EBSCOhost, accessed Dec. 24, 2013)

Lusardi, A. 2012. Numeracy, financial literacy, and financial decision-making, Numeracy 5(1): Article 2. http://dx.doi.org/10.5038/1936-4660.5.1.2 (accessed April 1, 2013).

Nye, P. and C. Hillyard. 2013. Personal financial behavior: The influence of quantitative literacy and material values. Numeracy 6(1): Article 3. http://dx.doi.org/10.5038/1936-4660.6.1.3 (accessed Dec. 24, 2013).

Ohlson, J. A. 1980. Financial ratios and the probabilistic prediction of bankruptcy. Journal of Accountancy Research 18 (1): 109-131. (Business Source Premier, EBSCOhost, accessed Oct. 30, 2013). http://dx.doi.org/10.2307/2490395

Remund, David L. 2010. Financial literacy explicated: The case for a clearer definition in an increasingly complex economy. The Journal of Consumer Affairs 44 (2): 276-295. http://dx.doi.org/10.1111/j.1745-6606.2010.01169.x

Ropega, J. 2011. The reasons and symptoms of failure in SME. International Advances in Economic Research, 17 (4): 476-483. http://dx.doi.org/10.1007/s11294-011-9316-1

SBA. See Small Business Administration

Shane, Scott. 2012. Start up failure rates: The definitive numbers. Small Business Trends, December 17, 2012. http://smallbiztrends.com/2012/12/start-up-failure-rates-the-definitivenumbers.html (accessed Dec. 14, 2013). 
Small Business Administration. 2013a. Small business trends. http://www.sba.gov/content/small-business-trends (accessed Aug. 3, 2013).

Small Business Administration. 2013b. Small business size regulations. http://www.sba.gov/content/small-business-size-regulations (accessed Aug. 3, 2013).

Small Business Administration. SBAc. Annual Report of the Office of Economic Research FY 2012. http://www.sba.gov/sites/default/files/12_OER_Ann_Rpt_0.pdf (accessed April 1, 2013).

Sevilla, A. N., and K. Somers. 2007. Quantitative reasoning: tools for today's informed citizen. Emeryville CA: Key College Publishing

The White House Blog. 2010. Small Businesses: "The Backbone of America's Economy." http://www.whitehouse.gov/blog/2010/05/13/small-businessesbackbone-americas-economy (accessed August 4, 2013)

Thomas III, J., and R. V. Evanson. 1987. An empirical investigation of association between financial ratio use and small business success. Journal of Business Finance \& Accounting 14, no. 4; 555-571. (Business Source Premier, EBSCOhost, accessed Oct. 30, 2013). http://dx.doi.org/10.1111/j.1468-5957.1987.tb00112.x

U.S. Treasury. 2010. Financial education core competencies. Federal Register, Vol 75 (165).

Vacher, H. L. 2014. Review of Financial Intelligence for Entrepreneurs: What You Really Need to Know about the Numbers by Karen Berman and Joe Knight, with John Case. Numeracy 7(1): Article 8. http://dx.doi.org/10.5038/1936-4660.7.1.8.

\section{Appendix: Observations}

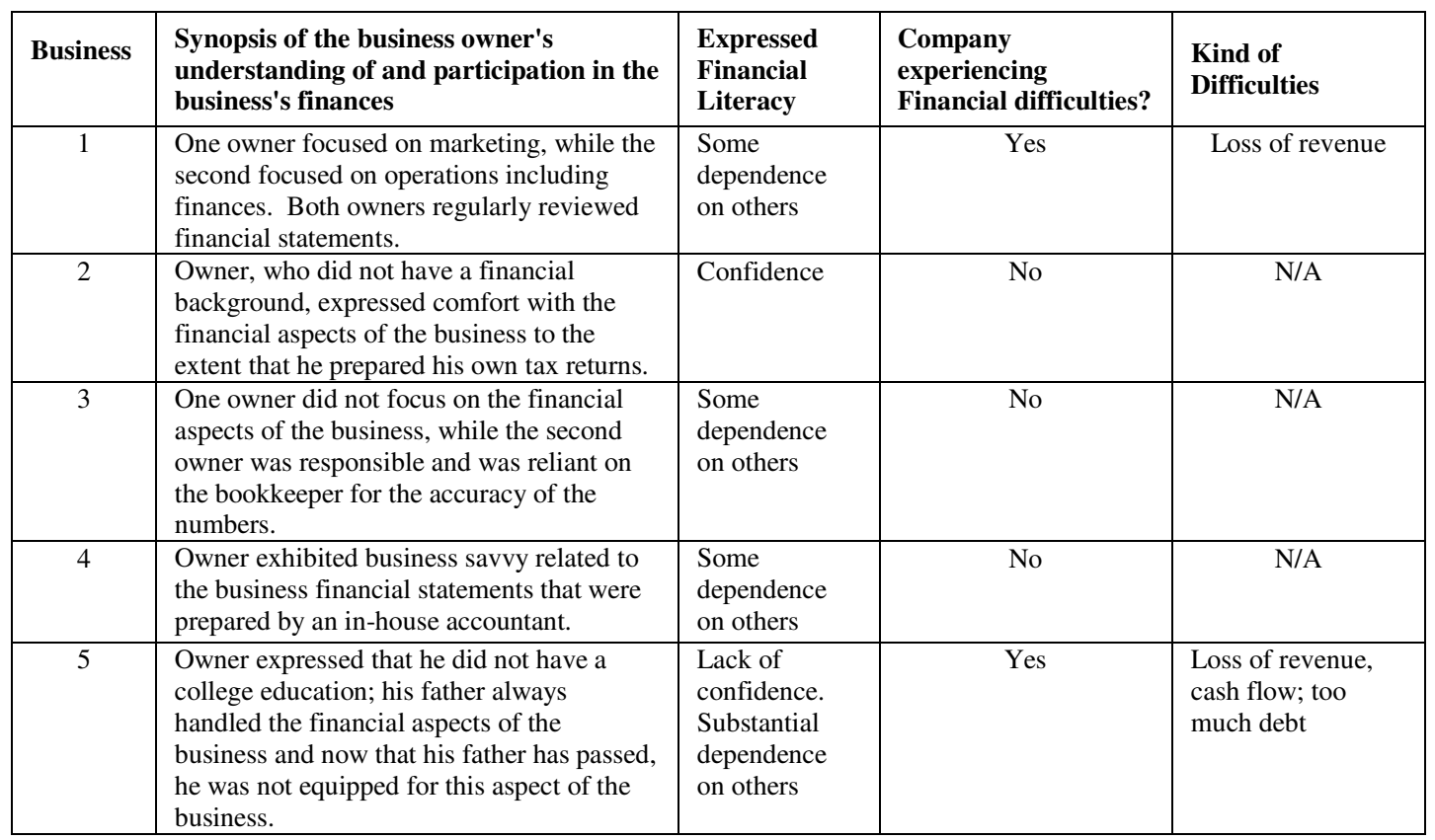


Numeracy, Vol. 7 [2014], Iss. 1, Art. 3

\begin{tabular}{|c|c|c|c|c|}
\hline 6 & $\begin{array}{l}\text { Owner focused on the numbers, and } \\
\text { questioned the accountant preparing them } \\
\text { on a regular basis. }\end{array}$ & Confidence & Yes & $\begin{array}{l}\text { Loss of revenue, } \\
\text { cash flow }\end{array}$ \\
\hline 7 & $\begin{array}{l}\text { Owner focused on financials and reviewed } \\
\text { the "numbers" in relation to all decisions. }\end{array}$ & Confidence & No & N/A \\
\hline 8 & $\begin{array}{l}\text { Owner expressed that when working in } \\
\text { Fortune } 500 \text { companies, financial matters } \\
\text { were handled by others. }\end{array}$ & Confidence & Yes & Cash Flow \\
\hline 9 & $\begin{array}{l}\text { Owner expressed spending time focused on } \\
\text { financial matters in order to create best } \\
\text { pricing model to grow business and } \\
\text { improve profits. }\end{array}$ & Confidence & No & N/A \\
\hline 10 & $\begin{array}{l}\text { Owner was totally dependent upon tax } \\
\text { preparer and did not review financial } \\
\text { statements. }\end{array}$ & $\begin{array}{l}\text { Lack of } \\
\text { confidence. } \\
\text { Substantial } \\
\text { dependence } \\
\text { on others } \\
\end{array}$ & Yes & $\begin{array}{l}\text { Loss of revenue, } \\
\text { cash flow; too } \\
\text { much debt }\end{array}$ \\
\hline 11 & $\begin{array}{l}\text { One owner focused on finances and } \\
\text { expressed competency with financial } \\
\text { literacy, while the second owner stated that } \\
\text { she was not good with numbers and did not } \\
\text { focus on this aspect of the business. }\end{array}$ & Confidence & No & N/A \\
\hline 12 & $\begin{array}{l}\text { Owner did not focus on finances in making } \\
\text { business decisions }\end{array}$ & $\begin{array}{l}\text { Some } \\
\text { Dependence } \\
\text { on Others }\end{array}$ & Yes & $\begin{array}{l}\text { Loss of revenue, } \\
\text { cash flow; too } \\
\text { much debt }\end{array}$ \\
\hline 13 & $\begin{array}{l}\text { Owner left the management of the business } \\
\text { in the hands of hired managers. }\end{array}$ & $\begin{array}{l}\text { Dependence } \\
\text { on Others }\end{array}$ & Yes & $\begin{array}{l}\text { Loss of revenue, } \\
\text { cash flow; too } \\
\text { much debt }\end{array}$ \\
\hline 14 & $\begin{array}{l}\text { Owner plainly stated she was "not a } \\
\text { numbers person" and did not look at } \\
\text { financials feeling that if she did not have to } \\
\text { contribute cash to the company it was } \\
\text { successful }\end{array}$ & $\begin{array}{l}\text { Lack of } \\
\text { confidence. } \\
\text { Substantial } \\
\text { dependence } \\
\text { on others } \\
\end{array}$ & No & N/A \\
\hline
\end{tabular}

